\title{
Multi-Scenario Spatial Modeling of PLTAL Distribution in Indonesia to Support Clean and Affordable Energy
}

\author{
Kalingga Titon Nur Ihsan ${ }^{\mathrm{a}, \mathrm{b},{ }^{*}, \text { Elstri Sihotang }}{ }^{\mathrm{a}, \mathrm{b}}$, Tania Septi Anggrainia ${ }^{\mathrm{a}, \mathrm{b}}$ \\ ${ }^{a}$ Remote Sensing and Geographic Information Science Research Group, Faculty of Earth Sciences and Technology, Institut \\ Teknologi Bandung, Indonesia \\ ${ }^{\mathrm{b}}$ Center for Remote Sensing, Institut Teknologi Bandung, Indonesia \\ *Correspondence: kalinggatitonnurihsan@gmail.com
}

KEY WORDS: Renewable energy, ocean currents, remote sensing, Ocean Current Power Plant, socioeconomic, spatial

\begin{abstract}
:
Increasing consumption of non-renewable energy has become a topic of global problems today due to its limited availability with a high potential for environmental damage. Seeing these problems, it is necessary to develop renewable energy that is more environmentally friendly and has great potential in Indonesia. One of Indonesia's potentials is an archipelago country with the second-largest coastline in the world with a coastline of 108,000 km. This causes Indonesia to have quite a large potential for ocean currents, namely around $1.5 \mathrm{~m} / \mathrm{s}$ and reaching 2.5-3.4 m/s for the Nusa Tenggara region. The energy of ocean currents has the potential to be developed because of its relatively stable and predictable nature. Good planning by observing the potential resources and energy needs spatially is needed in the process of managing and utilizing energy in a maximum and sustainable manner. This study aims to analyze areas that have the potential to generate ocean current energy in Indonesia and utilize spatial and socioeconomic elements to determine the effective and efficient distribution of Ocean Current Power Plants (PLTAL), especially for coastal areas and small islands. This study will integrate multi-dynamic spatial data, such as ocean current data, electrification needs of each region, economic and transportation data, as well as a model of potential land availability based on remote sensing data. The result of this research is in the form of priority analysis of PLTAL development in Indonesia in terms of energy output, spatial aspects, and socioeconomic aspects. It is hoped that the results of this study can be used as considerations and solutions for policymakers in making decisions regarding the development of PLTAL in Indonesia, especially to meet the energy needs of coastal areas and small islands.
\end{abstract}

\section{INTRODUCTION}

As time goes by, concerns over environmental damage caused by greenhouse emissions from fossil fuels, the use of volatile energy and waste around the production of fossil fuels emakin increased (Nicholas \& James, 2012). In 2019 the world's energy commisumi reached 158,839 TWh. The most commercialized energy produced from nonrenewable energy such as oil contributed 53,620 TWh,coal amounted to 43,849 TWh and ga amounted to 39,292 TWh (Smil,2016). In the midst of such issues renewable energy appears and is projected as the fastest growing source of energy (Energy, 2010). In Indonesia energy consumption is used in several fields, among others in the industry, households, transportation, agriculture and other sectors and the provision of energy is mostly non-renewable natural resources such as coal, crude oil, naturalgas, and biomass (Elinur,D, Mangara,\& Muhama,2010). The increase in the consumption of un renewable energy is a topic of global problems today due to its limited willingness and high potential for environmental damage. Therefore, renewable energy development is needed to meet the growing consumption of energy. Renewable energy is energy obtained from the flow of energy that repeats naturally and continuously occurs in the local tingkagan (Jhon \& Tony, 2015)

As an indonesian archipelago has the second longest coastline in the world, which is along 99,181 kilometers with an area of sea waters reaching 6.8 million square,which is $71 \%$ of the entire territory of Indonesia (KKP \& Indonesia, 2019). This causes Indonesia to have a considerable sea current potential of $1.5 \mathrm{~m} / \mathrm{s}$ and reach $2.5-3.4 \mathrm{~m} / \mathrm{s}$ for the Nusa Tenggara region. Marine current energy has a high potential to be developed because of its relatively stable and predictable nature. Good planning by looking at the potential of resources and energy needs spatially required in the process of development and management of energy to the maximum and sustainable. The utilization of spatial elements and sosioekomomi data is expected to determine the potential area to determine the distribution of Sea Current Power Plants (PLTAL) that are effective and efficient, especially for coastal areas and small islands.

The purpose of this study isto determine the distribution of pltal in Indonesia effectively by using a multi-scenario spatial model,menganalisis any factor that is a consideration in the determination of effective and efficient nuclear power plant, and determinethe level of trust of the distribution of pltal in coastal areas in Indonesia. With this research, it is expected that meng optimizethe poteni of marine aru power in the pesisisr region in Indonesia efficiently,memhelp the government in determining the construction site of nuclear power plants in Indonesia effectively and efficiently,and mememnuhi access to electricity in coastal areas and small islands that have not been supplied with electricity. 


\section{DATA AND METHOD}

\subsection{Data}

The data used in this study can be seen in table Table 1 below,

Table1 Data used in this research

\begin{tabular}{|c|c|c|c|c|c|}
\hline $\begin{array}{l}\mathrm{N} \\
\mathrm{O}\end{array}$ & Data & Unit & Source & Years & $\begin{array}{c}\text { Resoluti } \\
\text { on }\end{array}$ \\
\hline 1 & the & $\mathrm{m}$ & $\begin{array}{l}\text { http://diva- } \\
\text { gis.org/gdata }\end{array}$ & 2011 & $30 \mathrm{~s}$ \\
\hline 2 & $\begin{array}{l}\text { Protected } \\
\text { Area }\end{array}$ & - & $\begin{array}{c}\text { World Database } \\
\text { on Protected } \\
\text { Areas }\end{array}$ & 2019 & - \\
\hline 3 & $\begin{array}{c}\text { Electrificati } \\
\text { on }\end{array}$ & In & $\begin{array}{c}\text { https://zenodo.or } \\
\text { g/record/362814 } \\
\text { 2\#.X8W3WM0z } \\
\text { Y2z }\end{array}$ & $\begin{array}{c}2015- \\
2019\end{array}$ & $1 \mathrm{~km}$ \\
\hline 4 & $\begin{array}{c}\text { Human } \\
\text { Developmen } \\
\text { t Index }\end{array}$ & - & $\begin{array}{c}\text { Central Bureau } \\
\text { of Statistics }\end{array}$ & 2019 & $\begin{array}{l}\text { Provinci } \\
\text { al Level }\end{array}$ \\
\hline 5 & $\begin{array}{l}\text { Population } \\
\text { Density }\end{array}$ & $\underset{2}{/ \mathrm{Km}}$ & $\begin{array}{c}\text { https://www.bps } \\
\text {.go.id/publicatio } \\
\text { n/2019/07/04/da } \\
\text { ac1ba18cae1e90 } \\
\text { 706ee58a/statisti } \\
\text { k-indonesia- } \\
\text { 2019.html }\end{array}$ & 2018 & $\begin{array}{l}\text { Provinci } \\
\text { al Level }\end{array}$ \\
\hline 6 & Area $3 Y$ & - & $\begin{array}{c}\text { Presidential } \\
\text { Regulation No. } \\
131 \text { of } 2015 \text { on } \\
\text { Determination } \\
\text { of } \\
\text { Disadvantaged } \\
\text { Areas }\end{array}$ & 2015 & $\begin{array}{l}\text { District/ } \\
\text { City } \\
\text { Level }\end{array}$ \\
\hline 7 & $\begin{array}{l}\text { Current } \\
\text { Speed }\end{array}$ & $\mathrm{m} / \mathrm{s}$ & $\begin{array}{c}\text { https://ncss.hyco } \\
\text { m.org/thredds/n } \\
\text { css/grid/GLBv0. } \\
\text { 08/expt_93.0/uv } \\
\text { 3z/dataset.html }\end{array}$ & 2019 & $\begin{array}{c}6 \\
\text { minute }\end{array}$ \\
\hline 8 & $\begin{array}{l}\text { Location of } \\
\text { PLTAL in } \\
\text { Indonesia }\end{array}$ & - & - & 2020 & - \\
\hline
\end{tabular}

The parameters of the protected area are carried out buffer analysis with the specified distance indicated by Table 2 . After the buffer analysis process is done, the next is the scoring for each criterion.

\section{Scoring}

The scoring of each spatial parameter can be seen in Table 2 below 
Table 2 Spatial Aspect Parameters and Criteria

\begin{tabular}{|c|c|c|c|}
\hline Parametr & Sub Criteria & Shoes & Reference \\
\hline \multirow{2}{*}{$\begin{array}{c}\text { Slope slope } \\
\text { of DEM }\end{array}$} & $<\% 25$ & 3 & \multirow{4}{*}{$\begin{array}{l}\text { (Gašparović } \\
\& \\
\text { Gašparović, } \\
\text { 2019) }\end{array}$} \\
\hline & $\geq 25$ & 1 & \\
\hline \multirow{2}{*}{$\begin{array}{l}\text { Protected } \\
\text { Area }\end{array}$} & $\geq 10$ & 3 & \\
\hline & $<10$ & 1 & \\
\hline
\end{tabular}

\subsubsection{Modeling based on socio-economic aspects}

The modeling process based on socioeconomic aspects is divided into the following stages:

\section{Electrification and Regional 3T Data Processing}

Based on the electrification data used, it is divided into two classes, namely the class that is supplied with electricity and not. Scoring is done to convert the data into quantitative data, where a score of 3 is given for areas that have not been supplied with electricity, and a score of 1 is given for areas that have been supplied with electricity. Then for 3T area data, classification is done into $3 \mathrm{~T}$ and non-3T areas. Referring to what is the target of the government, where the $3 \mathrm{~T}$ area becomes the priority location of plts development, so that the $3 \mathrm{~T}$ area is given a higher score than non-3T areas, as shown by Figure3.


Figure 3 Electrification and Regional 3T Data Scoring

\section{HdI Classification and Population Density}

HdI classification refers to the standard used by the Central Bureau of Statistics, after which a score is performed for each criterion as shown by Figure 4. The same is also done for population density data where classification and scoring of the data (Statistics, 2010).
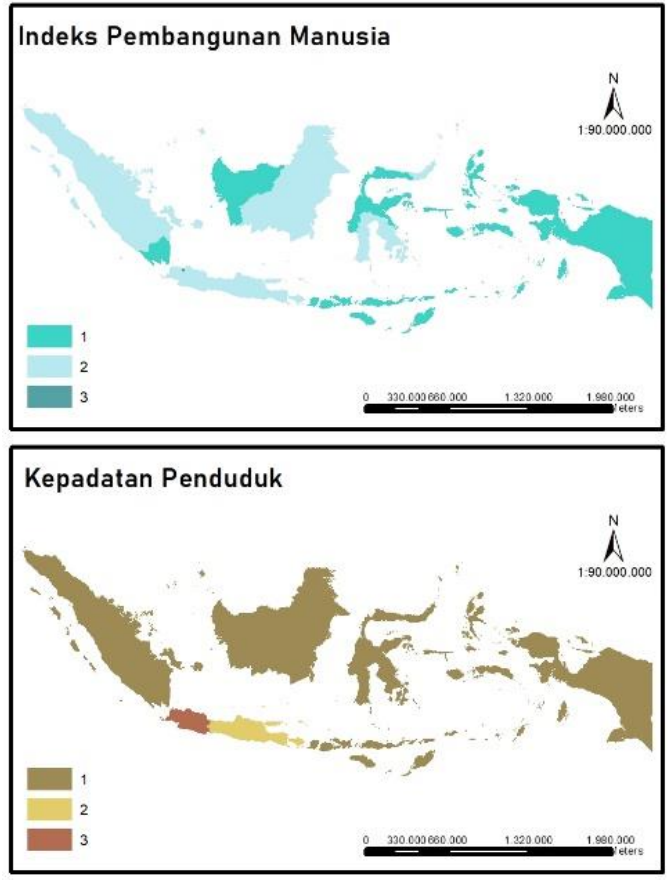

Figure 4 IPM Data Scoring and Population Density

\section{Scoring}

The scoring of each spatial parameter can be seen in table Table 3 below

Table 3 Parameters and Criteria for Socioeconomic Aspects

\begin{tabular}{|c|c|c|c|}
\hline Parameter & Sub Criteria & Shoes & Reference \\
\hline \multirow{2}{*}{ Electrification } & $\begin{array}{c}\text { Supplied with } \\
\text { electricity }\end{array}$ & 1 & \multirow{2}{*}{$\begin{array}{c}\text { (Gašparović } \\
\& \\
\text { Gašparović, } \\
\text { 2019) }\end{array}$} \\
\hline & $\begin{array}{l}\text { Not yet supplied } \\
\text { with electricity }\end{array}$ & 3 & \\
\hline \multirow{3}{*}{$\begin{array}{c}\text { Human } \\
\text { Development } \\
\text { Index }\end{array}$} & $\geq 80$ & 1 & \multirow{3}{*}{$\begin{array}{l}\text { (Statistics, } \\
\text { 2019) }\end{array}$} \\
\hline & $70-80$ & 2 & \\
\hline & $60-70$ & 3 & \\
\hline \multirow{3}{*}{$\begin{array}{l}\text { Population } \\
\text { Density }\end{array}$} & $\geq 1250$ & 3 & \multirow{3}{*}{$\begin{array}{l}\text { (Statistics, } \\
\text { 2010) }\end{array}$} \\
\hline & $500-1249$ & 2 & \\
\hline & $<500$ & 1 & \\
\hline \multirow{2}{*}{ Area 3Y } & Area 3Y & 3 & \multirow{2}{*}{$\begin{array}{c}\text { (Kencana, et } \\
\text { al., 2018) }\end{array}$} \\
\hline & Non-Regional 3T & 1 & \\
\hline
\end{tabular}

\subsubsection{Effective Power Modeling of PLTAL}

In modeling the effective power of PLTAL, it must first know the speed of current in each region. The current speed in the data has speed on vector you and vector v, so it needs to be calculated as a vector resultant to know the current speed. In calculating the resultant current speed can be used

$$
\text { Kecepatan }=\sqrt[3]{U^{2}+V^{2}}
$$

Where you is the current speed in the direction of vectors you $(\mathrm{m} / \mathrm{s})$ and $\mathrm{V}$ is the current speed in vector $\mathrm{v}(\mathrm{m} / \mathrm{s})$. Obtained results as in Figure 5. 




Figure 5 Current Speed

Once obtained the current speed, it can then be calculated the effective power of the ocean current adopts the equation of (Noir, P, et.al., 2015). The equation used is as follows.

$$
\mathrm{P}=1 / 2 \times \mathrm{r} \times \mathrm{v}^{\wedge} 3 \times
$$

Where $P$ (Watt) is the Effective Energy of a power plant, $\rho$ is the period of seawater type $(1025 \mathrm{~kg} / \mathrm{m} 3), \mathrm{v}$ is the current speed $(\mathrm{m} / \mathrm{s}), \mathrm{A}$ is the area of turbines used with an area of $1.2 \mathrm{~m} 2 . \eta$ is a coeficient generator $(\%)$ with a value of $79.07 \%$. Furthermore, it is scored by means of Geometrical Interval classification because it is considered most suitable for current models.

\subsubsection{Incorporation of 3 Conformity models}

The three models above, combined into one. However, in merging has constraints that are different study areas. In spatial and socio-economic areas are more reviewed on land areas, on the contrary in areas of potential effective current power, more reviewed in areas of sea waters. Therefore, to combine the two, a buffer is carried out on a land area of $20 \mathrm{~km}$ (approach of 12 miles or the length of territorial sea in Indonesia).

\section{RESULT AND DISCUSSION}

\subsection{Spatial and Socio-Economic Modeling}

Spatial and socio-economic model data combined their scoring values and regrouped into five conformity classes based on equal intervals. The results of spatial and socio-economic modeling are shown in Figure Kesalahan! Sumber referensi tidak ditemukan. below.

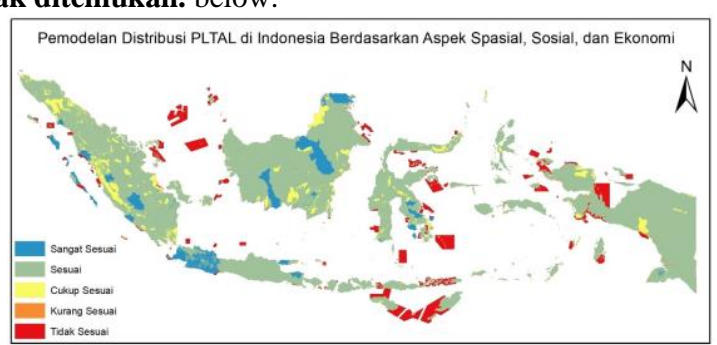

Figure 2 Spatial and socio-economist modeling results

Based on the results of spatial and socio-economic modeling, the area of conformity in Indonesia is dominated by appropriate and very high classes. Spatial modeling is done to see the effectiveness of electricity distribution to land areas through slope data and so that the construction of pltal is not in protected areas. Socio-economic modeling, carried out so that the distribution of pltal can be precisely targeted based on needs.

\subsection{Effective Power Potential Modeling}

Flow speed data after processing produces effective power potential. The potential data is then grouped into 5 conformity classes based on geometrical intervals. The results can be seen in Figure Kesalahan! Sumber referensi tidak ditemukan. below

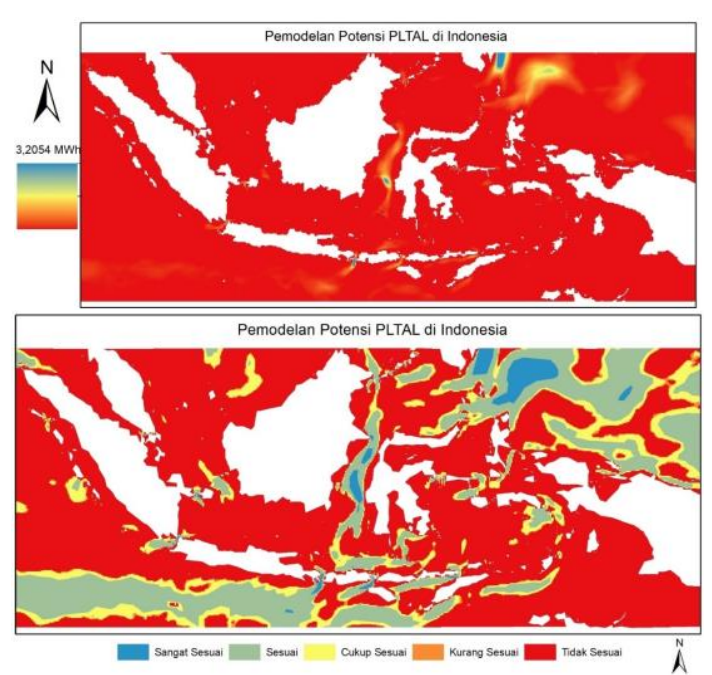

Figure 3 Effective power potential modeling results

Based on the results obtained that the area of pltal is very suitable found in the strait area (sea between two islands). This means that the speed of sea currents in the strait area has a higher speed when compared to other areas. From the results, paling areais found in the sea area of Indonesia is an area that is not suitable for pltal built.

\subsection{Multi Scenario Modeling}

Spatial, socio-economic, and effective power model data are further combined resulting in multiskenario modeling which can be seen in Figure Kesalahan! Sumber referensi tidak ditemukan. below.

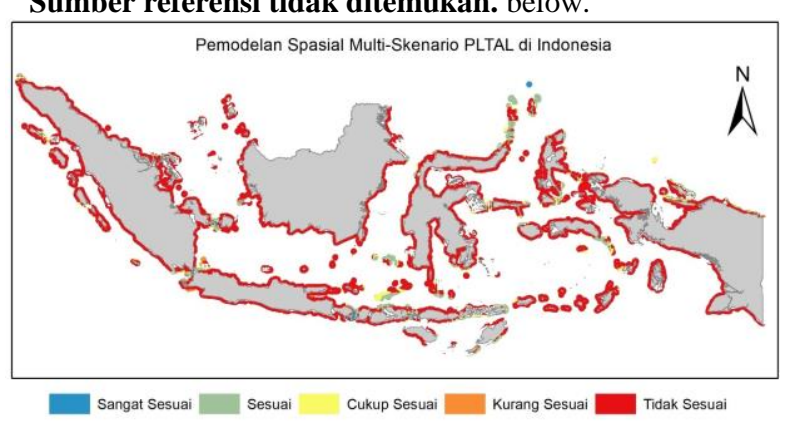

Figure 4 Multi-scenario modeling

Based on the results of multiskenario modeling, it was obtained that as a large coastal area in Indonesia has a class of conformity is not appropriate to be built pltal. When reviewed by province, 19 provinces have the highest compliance areas, including Aceh, West Sumatra, Riau Islands, Bangka Belitung, Lampung, Banten, West Kalimantan, East Kalimantan, North Sulawesi, Central Sulawesi, South Sulawesi, Bali, NTB, NTT, Maluku, North Maluku, Papua, and West Papua. From these results, it can be seen that pltal will be very potential if built between small islands such as in Nusa Tenggara and North Maluku. Spatially viewable in Figure Kesalahan! Sumber referensi tidak ditemukan. below. 


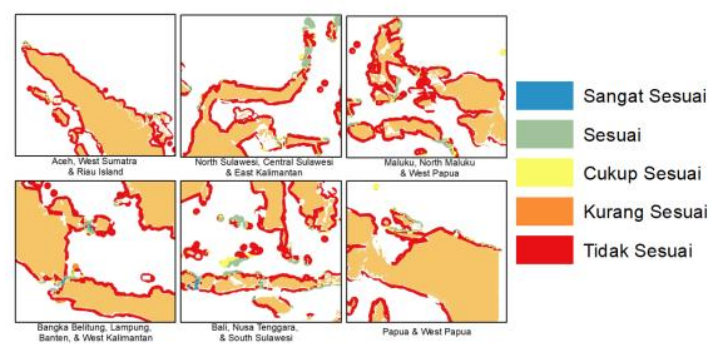

Figure 5 Multi-scenario modeling by province

The area of conformity of multiskenario spatial model of PLTAL distribution in Indonesia is dominated by the NonConforming area that can be seen in Figure Kesalahan! Sumber referensi tidak ditemukan. The appropriate area is approximately only $6.6 \%$ while the most suitable area is about $2 \%$. This is due to the influence of low effective power potential in the area. So, not all areas have good potential to be established PLTAL.

Based on the graph in Figure Kesalahan! Sumber referensi tidak ditemukan. obtained that 15 provinces that have the highest percentage of conformity area, namely Jakarta Raya, Riau Islands, Kalimantan Selantan, Lampung, Central Sulawesi, Bali, Bangka Belitung, North Maluku, Banten, South Sulawesi, Papua, Maluku, NTT, NTB, and North Sulawesi. Hopefully, with the construction of this power plant can help coastal areas and small islands to get access to electricity.



Figure 6 Area of Conformity of Spatial Model Multiskenario Distribution pltal in Indonesia

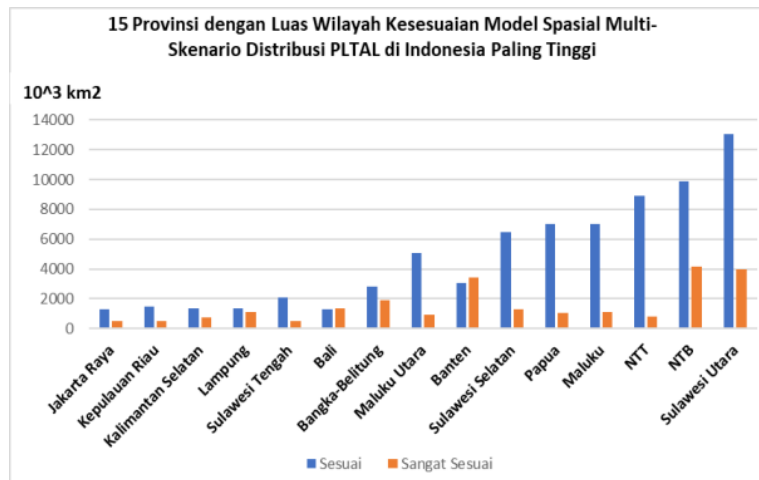

Figure 7 Area of conformity of multi scenario spatial model of PLTAL distribution in Indonesia is highest

The results of this study are compared to the plan to build nuclear power plants in Indonesia conducted by the Ministry of Energy and Mineral Resources. According to the Ministry of Energy and Mineral Resources the area to be built pltal is in the pantar strait, Alor Regency, East Nusa Tenggara. Based on the results of this study, in terms of current energy in the region is very appropriate. However, based on the socio-ecnomic aspects of the area is not suitable for construction pltal. That is because the area is a marine conservation area known as other effective area-based conservation measures (OECM) according to the Ministry of Marine Affairs and Fisheries (Redakasi, 2020),so that the area can not be built pltal.

\subsection{Multi Scenario Modeling}

Data validation is done with EBTKE data in accordance with Figure Kesalahan! Sumber referensi tidak ditemukan. and Figure Kesalahan! Sumber referensi tidak ditemukan. From the picture, it can be seen that the PLTASL area has a very suitable current speed but, the laying of pltal is in a protected area that should not be built. However, this data sufficiently validates the resulting current data.

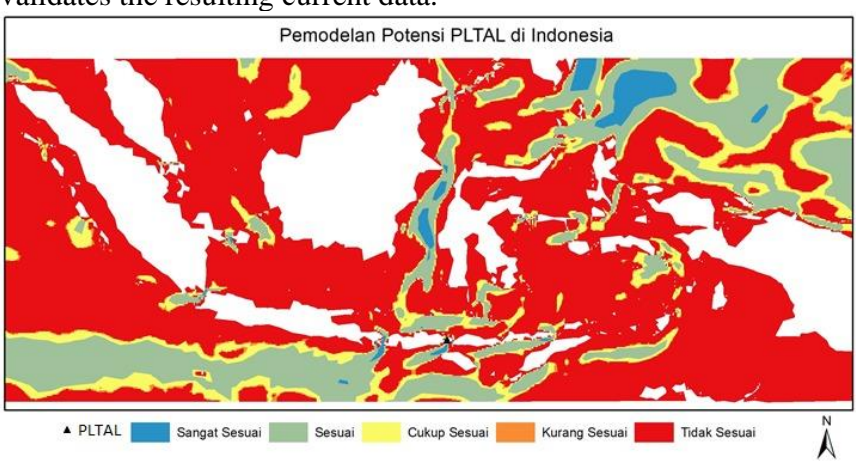

Figure 8 Pltal validation in Indonesia based on current data



Figure 9 Validation of PLTAL position based on socioeconomic and spatial data

\section{CONCLUSION}

Pltal distribution was successfully determined, from the results can be seen that only about $8.5 \%$ of areas in Indonesia have a high conformity to be established PLTAL. The determining factor of effective and efficient pltal conformity location should be reviewed from three aspects, namely spatial, socio-economic and effective power aspects of current. This research can be developed again by including other spatial factors that affect in determining the suitability of pltal location. In addition, in the use of ocean currents can be developed to use sea current data at an even higher resolution. The results of this study can also be developed by validation to the field to the area of conformity.

\section{ACKNOWLEDGEMENTS}

The authors are grateful to acknowledge the support from Earth Research Collaboration Program by Faculty of Earth Sciences and Technology, Institut Teknologi Bandung. We also thank the anonymous reviewers whose valuable comments greatly helped us to prepare an improved and clearer version of this paper. All persons and institutes who kindly made their data available for this analysis are acknowledged.

\section{REFERENCES}

Arderne, C., Zorn, C., \& Koks, E. (2020). Predictive mapping of the global power system using open data. Scientific data, 7(1), 1-12.

Beben, R., Ai, T., \& Prijantono, A. (2013). PRELIMINARY RESEARCH ON THE PLACEMENT OF TURBINES IN THE Early Settlement of Marine Current Power Plant Turbines 
(PLTAL) from The Current and Morphology Data of Dasra Laut in Boleng Strait, East Nusa Tenggara. Journal of Marine Geology, Voll, No 1.

Elinur, D, P., Mangara, T., \& Muhama, F. (2010). Development of Energy Consumption and Energy Supply in the Economy. Indonesia Journal of Agricultural Economics, Vol 2, no 1.

Energy, O. I. (2010). U.S.Energy Information Administration. Departement of Energy. Washington, DC.

Erwandi. (2006). Current Energy Source: Alternative fuel replacement, Environmentally Friendly and Renewable. Indonesian Hydrodi-namika Laboratory, BPP Technology.

\section{ESDM.}

https://www.esdm.go.id/assets/media/content/content-rasioelektrifikasi.pdf. Ministry of Energy and Mineral Resources. Ferial. (2011). Development of Marine Current Energy. https://ebtke.esdm.go.id/.

Frankael, P. L. (2002). Power from Marine Currents, Proceedings of the Institution of Mechanical Engineers. Part A: J.Power and Energy, Vol 216, No 1, pp.1-4.

Gašparović, I., \& Gašparović, M. (2019). Determining optimal solar power plant locations based on remote sensing and GIS methods: A case study from Croatia. Remote Sensing, XI, 1481.

IRENA. (2017). , Renewable Energy Prospects: Indonesia, a REmap analysis ( www.irena.org/remap.). Abu Dhabi: International Renewable Energy Agency .

Jhon, T., \& Tony, W. (2015). Renewable Energy Resources. Abingdon:Routledge: 3 ed.

Kencana, B., Prasetyo, B., Berchmans, H., Agustina, I., Myrasandri, P., Bona, R., . . . Winne. (2018). Guide to Feasibility Study of Centralized Solar Power Plants (PLTS). Jakarta: Tetra Tech ES.

KKP, \& Indonesia, K. K. (2019). The Future Sea of the Nation, Let's Keep It Together. kkp.go.id.

Lillesand, T., \& Kiefer, R. (1997). Remote Sensing and Image Interpretation (Translation). Yogyakarta: Gadjah Mada University Press.

Nicholas, A., \& James, P. E. (2012). Renewable and nonrenewable energy consumption-growth nexus: Evidence from apanel error correction model. Energy Economics, 733-738.

Parabelem, T. D., Ferry, J. S., \& Heindrich, T. (2016). Study on marine current with approach of a numerical model for marine current power plant (PLTAL) in the Bangka strait North Sulawesi. International Seminar on Application for Technology of Information and Communication (ISemantic), Semarang, 2016, pp. 104-110, doi: 10.1109/ISEMANTIC.2016.7873818.

Smil, V. (2016). Energy Transitions: Global and National Perspectives. Westport Praeger, 2 ed.

Statistics, B. P. (2010). Regulation of the Head of Central Statistics Agency number 37 of 2010. Plucked December 15, 2020 , https://sirusa.bps.go.id/webadmin/doc/MFD_2010_Buku_1.pdf
Statistics, B. P. (2019). Human Development Index 2019. Jakarta: Central Bureau of Statistics. 